\title{
Large Neutral Amino Acids Transporter Small Subunit 1
}

National Cancer Institute

\section{Source}

National Cancer Institute. Large Neutral Amino Acids Transporter Small Subunit 1. NCI

Thesaurus. Code C106590.

Large neutral amino acids transporter small subunit 1 (507 aa, $55 \mathrm{kDa}$ ) is encoded by the human SLC7A5 gene. This protein plays a role in both neutral amino acid transport and neurogenesis in the brain. 